\title{
The impact of semi-natural broadleaf woodland and pasture on soil properties and flood discharge
}

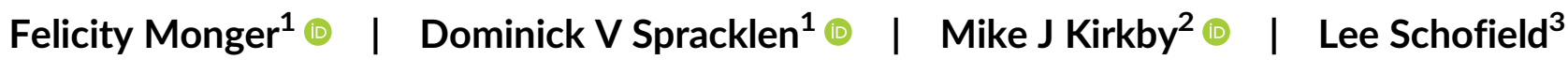

\author{
${ }^{1}$ School of Earth and Environment, University \\ of Leeds, Leeds, UK \\ ${ }^{2}$ School of Geography, University of Leeds, \\ Leeds, UK \\ ${ }^{3}$ RSPB Haweswater, Naddle Farm, Penrith, \\ Cumbria, UK

\section{Correspondence} \\ Felicity Monger, School of Earth and \\ Environment, University of Leeds, LS2 9JT, \\ Leeds, UK. \\ Email: eefam@leeds.ac.uk \\ Funding information \\ United Bank of Carbon
}

\begin{abstract}
Woodlands can reduce the risk of rainfall-generated flooding through increased interception, soil infiltration and available storage. Despite growing evidence, there is still low confidence in using woodlands as a flood mitigation method due to limited empirical data, particularly for broadleaf woodlands. We measured soil properties and streamflow for nine small $\left(<0.2 \mathrm{~km}^{2}\right)$ upland catchments and compared mature semi-natural broadleaf woodland where no stock grazing occurs to pasture with varied grazing intensity. We compared streamflow across 28 storm events including a 1 in 10-year event, two 1 in 4-year events and five 1 in 1.5-year events, identified over a 13-month period. We found that semi-natural broadleaf woodlands reduce specific peak discharge by $23 \%-60 \%$ and peak runoff coefficients by $30 \%-60 \%$ compared with pasture. Response to storm events took 14-50\% longer in woodland compared to pasture. These differences in flood response are partly explained by more permeable woodland soils, 11-20 times greater than pasture soil. The more muted response of wooded catchments to storm events is consistent across the storms investigated, including Storm Ciara, a 1 in 10-year event. Our analysis strengthens the argument that semi-natural woodlands can reduce rainfall-generated flooding contributing to the evidence base for natural flood management.
\end{abstract}

\section{KEYWORDS}

catchment-based flood management, natural flood management, pasture, soil permeability, woodland

\section{1 | INTRODUCTION}

Over the past three decades the frequency of flood events has increased across the UK (Rogger et al., 2017) and worldwide (Hall et al., 2014; Kundzewicz et al., 2014; Wingfield et al., 2019). In England, floods cause damages of $£ 1.1$ billion annually with one in six properties at risk from flooding (Priestley, 2017). This risk is expected to further increase under future climate change (lacob et al., 2017).
Because of recent floods, there is a growing interest in the use of 'soft-engineered' flood mitigation schemes (Dadson et al., 2017; Stevens et al., 2016). Natural Flood Management (NFM), also referred to as working with natural processes or nature-based solutions (Seddon et al., 2020), is an approach to flood management that seeks to work with natural processes to enhance the flood regulatory capacity of a catchment. Often these approaches also provide ecosystem services such as pollution assimilation, habitat creation and carbon storage (Hankin et al., 2017). NFM approaches may include the

This is an open access article under the terms of the Creative Commons Attribution-NonCommercial License, which permits use, distribution and reproduction in any medium, provided the original work is properly cited and is not used for commercial purposes.

(c) 2021 The Authors. Hydrological Processes published by John Wiley \& Sons Ltd. 
development of built water storage (Nicholson et al., 2020; Quinn et al., 2013), river restoration (Dixon et al., 2016), leaky debris dams (Ashbrook, 2020; Thomas \& Nisbet, 2012) and land-use management (Spray et al., 2016).

Land-use management can influence the generation of overland flow, through hydrological processes such as interception, infiltration into soils, and available water storage, making it a potentially impactful NFM approach (Stratford et al., 2017). However, there is limited empirical data regarding the impact of land-use management as an effective NFM strategy (Burgess-Gamble et al., 2017). Furthermore, the size of a storm event is an important variable influencing the effectiveness of NFM (Archer, 2007; Beschta et al., 2000; Gallart \& Clotet, 1987; Kirby, Newman, \& Gilman, 1991).

In the UK and across northern Europe, NFM is often used in headwater catchments of the uplands, which receive high volumes of precipitation and are ideally placed for schemes which aim to 'slow the flow' of water down-slope (Bronstert et al., 2002; Marshall et al., 2009; Wheater \& Evans, 2009). These areas are often dominated by grasslands used as permanent pasture (Marshall et al., 2009; Murphy et al., 2020), grazed by livestock, predominantly sheep. Grazing alters vegetation and can lead to soil compaction, loss of macro-porous soil structure and increased flood risk (Alaoui et al., 2018; Holden et al., 2007; Murphy et al., 2020; Palmer \& Smith, 2013; Sansom, 1999). Exclusion of livestock has been observed to alter vegetation structure and soil structure, leading to an increase in infiltration rates and a reduction in surface runoff (Gifford \& Hawkins, 1978; Greenwood et al., 1997; Marshall et al., 2009; Marshall et al., 2014; Nguyen et al., 1998).

Forested catchments have a different hydrological response compared to un-forested catchments due to greater interception, soil infiltration and available storage. Woodland soils typically have higher permeability rates than other vegetation types (Agnese et al., 2011; Archer et al., 2013; Mawdsley et al., 2017; McCulloch \& Robinson, 1993; Zimmermann et al., 2006). This is attributed to a more open structure found in woodland soils as a result of increased organic matter and the action of tree roots (Nisbet \& Thomas, 2006). Wooded catchments also have higher evapotranspiration and interception rates compared with other vegetation types, as trees are usually taller and have greater leaf area (Calder \& Aylward, 2006; Nisbet, 2005). This means woodlands can produce lower annual runoff compared to other land cover types, as demonstrated in numerous catchment-based studies including Stocks Reservoir (Law, 1956), Plynlimon (Hudson et al., 1997; Kirby et al., 1991); Coalburn (Birkinshaw et al., 2014; Robinson, 1998) and Balquhidder (Johnson, 1995), depending on hydrological regime and climate (Brown et al., 2005; Farley et al., 2005; Zhang et al., 2017). In addition to altering annual runoff, woodland tends to reduce and delay flood peaks (Dadson et al., 2017; Stratford et al., 2017). However, the benefit of woodlands in providing smaller peak flows is typically less for larger storms and larger catchments (Archer, 2007; Beschta et al., 2000; Gallart \& Clotet, 1987; Gallart \& Llorens, 2003).

Historically, UK catchment-scale hydrological studies have investigated the influence of conifer afforestation (Marshall et al., 2009).
UK forest cover increased from 5\% in 1920 to $13 \%$ in 2020 (Forestry Commission, 2020), largely due to expansion of conifer plantations, which now account for $51 \%$ of UK woodland area (Forestry Commission, 2020). Relatively few UK studies have focused on broadleaf woodlands, which are the natural vegetation type in much of the UK. Broadleaf woodlands are likely to have a different impact on hydrological processes. For example, evergreen conifers retain leaves all year and intercept $25 \%-40 \%$ of annual rainfall compared with 10\%-25\% for broadleaf deciduous woodland (Ahmad-Shah \& Rieley, 1989; Nisbet \& Broadmeadow, 2003; Roberts \& Rosier, 2005). In addition, broadleaf trees typically have deeper root systems and higher soil infiltration rates compared with conifers (Archer et al., 2013). Differences in woodland management are also likely to alter hydrology, with the drainage ditches and forest roads that are more likely to be present in a productive conifer plantation, contributing to increases in downstream peak flows (Bathurst et al., 2018; Bathurst et al., 2020; Robinson et al., 2003; Stratford et al., 2017). Furthermore, the occurrence of periodic felling in a productive conifer plantation removes the canopy and causes soil disturbance which may contribute to an increase in localized flood risk (Nisbet \& Thomas, 2006) and increased annual flows (Robinson \& Dupeyrat, 2005). In a study focused on China, Tembata et al. (2020) found that broadleaf and mixed forests mitigate flooding, but conifer forests do not.

There have been few comparisons between upland permanent pasture and broadleaf woodland, particularly studies that have measured both soil properties and streamflow response. Previous studies of broadleaf woodland creation (Marshall et al., 2014) have focused on the short-term impacts, as soon as 18-months after tree planting (Mawdsley et al., 2017). Research at Pontbren, one of the limited broadleaf woodland studies, found median soil infiltration rates were 67 times greater in newly ( $<5$ years) planted broadleaf woodlands compared with grazed pasture, with runoff volume reduced by 78\% (Carroll et al., 2004; Marshall et al., 2014). As areas of newly planted broadleaf woodland mature, it will be increasingly important to understand how established broadleaf woodlands impact both soil properties and streamflow, to better understand the potential for flood mitigation (Murphy et al., 2020).

In this study we report results from a research catchment consisting of mature broadleaf woodland and grazed pasture in the UK uplands. The aims of the study were to:

1. Quantify the impact of pasture and mature semi-natural broadleaf woodland on soil properties.

2. Analyse streamflow response, including peak flow and runoff coefficient, of catchments dominated by pasture and mature seminatural broadleaf woodland.

Our study is one of the first studies to investigate the impact of a mature broadleaf woodland in the UK, contributing to the evidence base around the benefits of broadleaf woodlands in the UK uplands. 


\section{2 | METHODS}

\section{1 | Study area}

This study took place around Haweswater reservoir $\left(54^{\circ} 31^{\prime} 50.9^{\prime \prime} \mathrm{N}\right.$, $2^{\circ} 45^{\prime} 37.3$ ”'W) in the Lake District National Park, UK (Figure 1). The land is owned by United Utilities and managed in partnership with the Royal Society for the Protection of Birds (RSPB) (RSBP, 2015). Elevations across the study area range from 243 to $720 \mathrm{~m}$. The site experiences mild winters and cool summers (Kenworthy, 2014), with mean monthly temperatures ranging from $-0.3^{\circ} \mathrm{C}$ to $18.3^{\circ} \mathrm{C}$. Mean annual precipitation is $1779 \mathrm{~mm}$, with monthly totals ranging from 88 to $231 \mathrm{~mm}$ (1981-2010 mean, derived from the Shap weather station at $255 \mathrm{~m} \mathrm{AoD}$ ) (Met Office, 2020). Average potential evapotranspiration (1961-2017) is $1.3 \mathrm{~mm} \cdot \mathrm{d}^{-1}$, with a summer average of $2.4 \mathrm{~mm} \cdot \mathrm{d}^{-1}$ and a winter average of $0.3 \mathrm{~mm} \cdot \mathrm{d}^{-1}$ (Robinson et al., 2020).

Soils in the study area are upland organo-mineral soils, predominately Malvern 611a (Chromic Endoleptic Umbrisol), a free draining acid loamy soil and Bangor 311e (Dystric Epileptic Histosol) soils, ordinarily described as very acidic peaty soil underlined by igneous rock (Cranfield University, 2019). Land use includes semi-natural broadleaf woodland and unimproved permanent pasture grazed at a variety of densities. In recent years, United Utilities and RSPB have trialled a number of upland land management strategies, including tree planting, moorland drain blocking and changes to grazing (RSBP, 2015).

\section{2 | Study design}

We identified nine small $\left(<0.2 \mathrm{~km}^{2}\right)$ catchments with different land covers but similar elevation, slope, geology and soil type (Table 1). We compared mature semi-natural woodland (W) and permanent pasture under either commons grazing (CG) or low-density grazing (LG). Woodland catchments consisted of mixed broadleaf species, predominantly oak, ash, alder, birch and hazel, with no stock grazing. Permanent pasture sites were unimproved (i.e., no drainage, ploughing or fertilizer application has occurred). Sheep grazing in CG occurs all year round at a maximum ewe intensity of 0.12 livestock units, LU.ha ${ }^{-1}$, whereas grazing intensity in LG never exceeded $0.10 \mathrm{LU} \cdot \mathrm{ha}^{-1}$, with no grazing in winter and scattered tree planting. Red and roe deer occurred at all sites.

\section{3 | Soil properties}

Soil properties were analysed on a monthly basis during a 12-month period (July 2018-July 2019) and sampled randomly across each catchment. Soil cores $(n=30)$ were taken at 0-5 cm depth, just below the vegetation layer using Eijelkamp soil sample rings. Top-soil permeability (saturated hydraulic conductivity, Kfs or Ksat) was measured in an Eijkelkamp 25 place Permeameter, from the collected soil cores. Subsoil permeability (Kfs or Ksat, $0.15 \mathrm{~m}$ depth) was determined infield using a constant head well permeameter (CHWP, Engineering Technologies Canada Ltd. [ETC] pask, $n=13$ ) (Elrick \& Reynolds, 1986; Reynolds, 2008). A pre-wetting phase was included to reduce the time to reach steady state flow and ensure saturation. The Eijelkamp Permeameter was unsuitable for the subsoil measurements due to the rocky nature of the ground. Bulk density $\left(\rho, \mathrm{g} \cdot \mathrm{cm}^{-3}\right)$ was calculated after oven drying ( $105^{\circ}$ for a minimum of $16 \mathrm{~h}$ ) the soil cores to constant weight. Soil moisture content was measured using a Delta-T Ltd 'theta probe' $(n=225)$. The 'theta probe' uses a simplified time-domain reflectometry (TDR) technique to derive values of volumetric moisture content (Delta-T, 1999).

\section{$2.4 \quad$ Hydrological monitoring}

Hydrology was monitored over a 13-month period (January 2019February 2020). A $90^{\circ}$ v-notch weir was established within each catchment, with a pressure transducer installed to collect stream depth data every 5 min (see Supplementary material 1 for details). Flow was calculated using the Kindsvater-Shen equation (Supplementary material 2). Locations for data collection within the streams were based on suitability of the channel bed; approximately $1.5 \mathrm{~m}$ between channel banks and accessibility for monthly equipment checks. Rainfall data (5 min resolution) was collected using a HOBO RG3 data logging tipping bucket rain gauge (Figure 1).

\section{5 | Storm response}

Storm events were defined when more than $20 \mathrm{~mm}$ of rain occurred during a 24-hr period. The end of the event was defined as 6 hours with no rain. During a 13-month period (January 2019-February
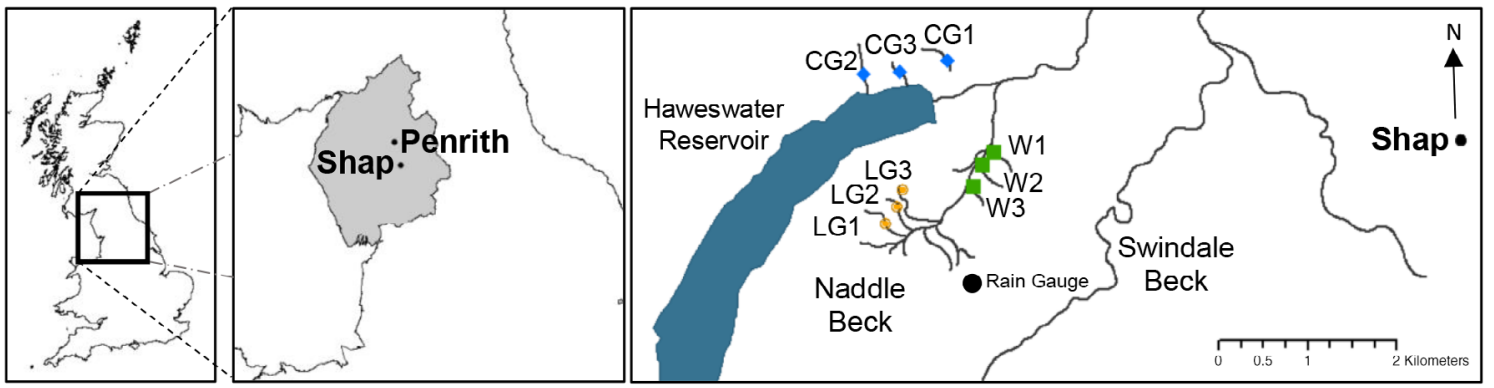

FIG URE 1 Map of field sites, RSPB Haweswater within the UK and location of rain gauge and woodland (W), commons grazing (CG) and lowdensity grazing $(\mathrm{LG})$ pasture 


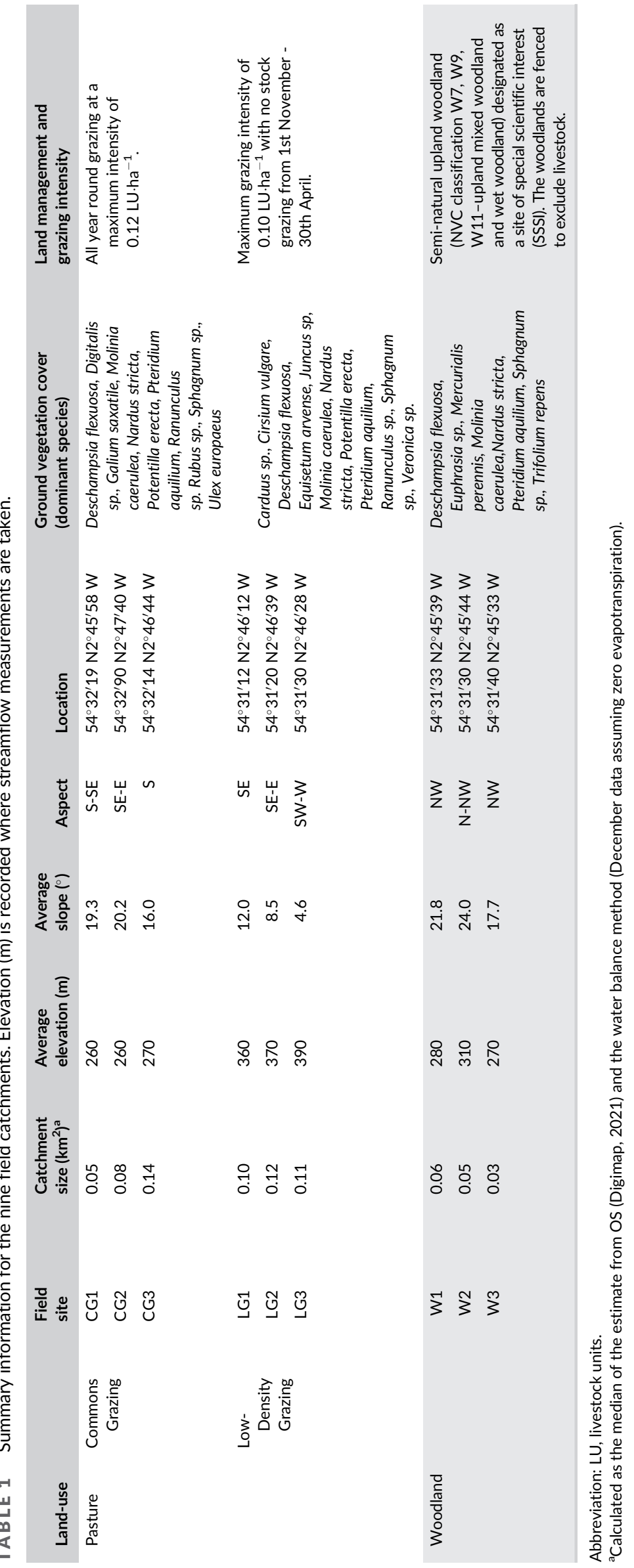


2020), 28 storms were identified including both winter and summer storms (Supplementary material 3). Storm durations ranged from 9.5 to 96.25 hours. Storm intensity, defined as total rainfall divided by storm duration, ranged from 0.62 to $5.3 \mathrm{~mm} \cdot \mathrm{hr}^{-1}$.

We used rainfall data from Wet Sleddale, $8 \mathrm{~km}$ from the site, to establish storm return periods as there was insufficient data available from the nearest rain gauge (Naddle). Rainfall at Wet Sleddale was highly correlated with records from Naddle (see Supplementary material 4). An IDF (intensity-duration-frequency) curve was used to calculate return periods.

Catchment response to each storm was analysed in four ways: The specific peak discharge, peak runoff coefficient, volume runoff coefficient and time to flow response. The specific peak discharge (SPD, $\mathrm{mm} \cdot \mathrm{hr}^{-1}$ ) indicates the highest discharge during the storm event with the influence of catchment area removed (Supplementary material 5). Both the peak runoff coefficient and volume runoff coefficient are dimensionless coefficients relating the amount of runoff to the amount of precipitation received and useful for catchment comparisons to understand how different landscapes impact runoff (Young et al., 2009). A larger runoff coefficient can indicate a catchment with lower infiltration rates that is more susceptible to flooding, whilst a smaller value suggests a more permeable catchment. Peak runoff coefficient $(C)$ is calculated by dividing the peak rate of runoff by the maximum rainfall intensity (Supplementary material 5 ). To determine the volume runoff coefficient (V) for each storm, baseflow was removed from the storm hydrograph and the total storm runoff calculated. The volume runoff coefficient was then calculated as the ratio of total storm runoff to total storm rainfall (Merz et al., 2006). The time to flow response is the time, in hours, between the initiation of rainfall and a significant water level rise (Gonzalez-Sosa et al., 2010), defined in our analysis as three times streamflow at the start of the event.

\subsection{1 | Influence of storm size and seasonality}

We analysed the impact of storm size by two different methods. Firstly, we used the classification of Kirby et al. (1991) with smaller storms classified as discharge peaks $<1 \mathrm{~mm} \cdot \mathrm{hr}^{-1}$ and larger storms as discharge peaks $>1 \mathrm{~mm} \cdot \mathrm{hr}^{-1}$, allowing for direct comparison with previous studies (Kirkby et al., 1991; Meyles et al., 2003). Secondly, we divided storms by storm return periods. Storms were divided into those with a return period less than 1.5 years and those with a return period longer than 1.5 years, with this threshold reflecting the average reoccurrence of bankfull stage (Wolman \& Miller, 1960). Our storm return periods are based on rainfall data, likely leading to longer return periods compared to return periods based on discharge data. There were insufficient large storm events in our study period to fully characterize the impact of land cover as a function of storm size.

We also identified whether the storms occurred during winter or summer and re-calculated the mean SPD, peak runoff coefficient, volume runoff coefficient and time to flow response. Finally we calculated the cumulative sum of flow above two different thresholds
( 1 and $2 \mathrm{~mm} \cdot \mathrm{hr}^{-1}$ ) between 03 March 2019 and 17 March 2019, a period when data was available at all sites and evapotranspiration can be assumed to be minimal.

\subsection{2 | Hydrograph form and flashiness}

We identified the $97.5 \%$ flow threshold and analysed each consecutive period of higher flow. The hydrograph within each of these peak periods was normalized relative to the peak flow in the period, allowing us to compare the relative rates of rise and fall around the peak, thereby providing an indication of the flashiness of the response. This procedure was followed for each measurement site. Since the sites are all close together (within $3.5 \mathrm{~km}^{2}$ ), the incidence of storm events was considered comparable, revealing the inherent differences in flashiness between the sites.

\section{6 | Statistical analysis}

Shapiro-Wilks tests were employed to deduce normality of soil properties and storm responses. Non-parametric Kruskal-Wallis and posthoc tests were used to determine a significant difference (significance determined at $p<0.05$ ) between land covers (significant differences between individual catchments can be found in Supplementary material 6 \& 8). Statistics were performed using the Python matplotlib (Barrett et al., 2005), SciPy (Virtanen et al., 2019) and scikit-posthocs (Terpilowski, 2019) packages.

\section{3 | RESULTS}

\subsection{Soil properties}

Woodland sites had significantly $(p<0.05)$ higher topsoil permeability compared with the pasture sites. Median topsoil permeability was 11 times higher in the woodland sites compared with CG sites, and 20 times higher than the LG sites (Figure 2a). There was no significant $(p>0.05)$ difference between subsoil permeability at the different sites (Figure 2b). The highest mean soil moisture occurred at the woodland sites (49\%), compared with LG (46\%) and CG (33\%) with significant $(p<0.05)$ differences between the soil moisture at the different sites (Figure $2 c)$. The lowest bulk density soils were measured at the LG sites $\left(0.36 \mathrm{~g} \cdot \mathrm{cm}^{-3}\right)$ compared with CG $\left(0.46 \mathrm{~g} \cdot \mathrm{cm}^{-3}\right)$ and W sites $\left(0.50 \mathrm{~g} \cdot \mathrm{cm}^{-3}\right)$ (Figure $2 \mathrm{~d}$ ). Details of the measurements for the nine catchments are given in Supplementary material 6 and 7.

\subsection{Storm response}

Figure 3 compares SPD, runoff coefficients and time to flow response across all the storms analysed. SPD and peak runoff coefficient were significantly lower at woodland sites compared with CG and LG sites 

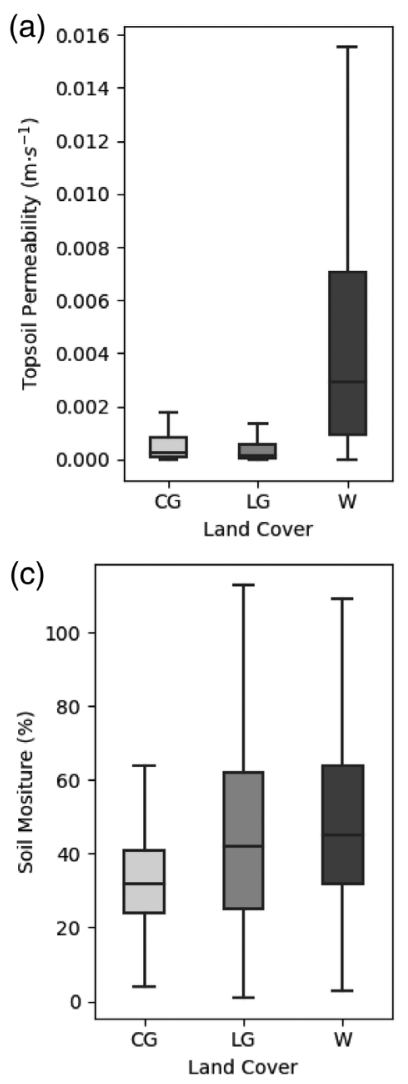
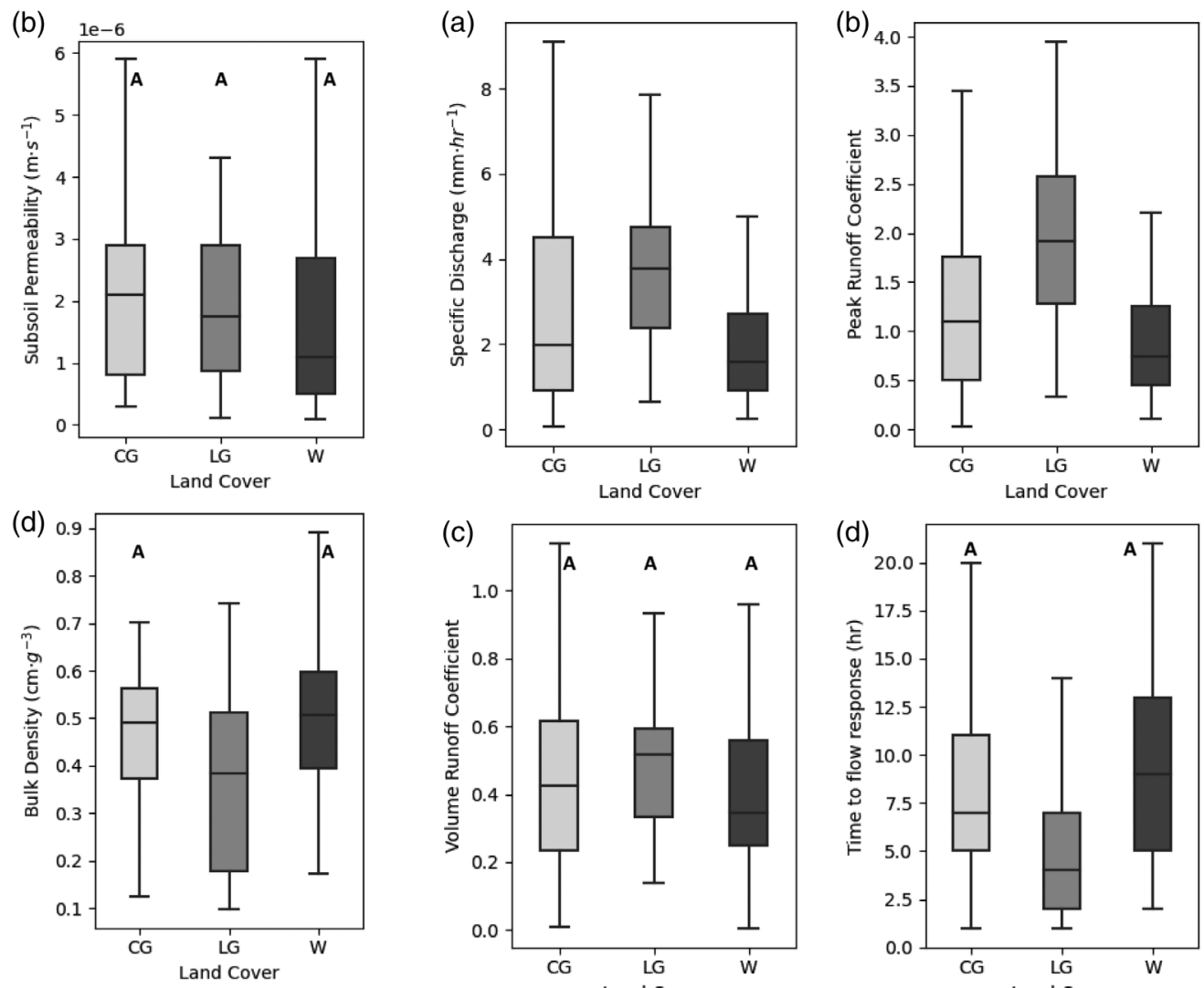

FIGURE 2 Distribution of (a) topsoil permeability $\left(\mathrm{m} \cdot \mathrm{s}^{-1}\right)$, (b) subsoil permeability $\left(\mathrm{m} \cdot \mathrm{s}^{-1}\right.$ ), (c) soil moisture (\%), (d) bulk density $\left(\mathrm{g} \cdot \mathrm{cm}^{-3}\right)$ for woodland $(\mathrm{W})$, commons grazing (CG) and low-density grazing (LG) pasture shown as median (line), 25\% and 75\% (box), and $5 \%$ and $95 \%$ (whiskers). Sites which are not statistically different share a letter

$(p<0.05)$. Woodland sites median SPD was $23 \%$ less than CG and $60 \%$ less than LG sites (Figure 3a). Woodland sites had a peak runoff coefficient $30 \%$ less compared with CG sites and $60 \%$ less LG sites (Figure $3 b$ ). Volume runoff coefficients were not significantly different between land covers (Figure 3c). The median time to flow response in woodland was $14 \%$ longer than CG sites and 50\% longer compared with LG sites (Figure 3d). Woodland sites had significantly different time taken to flow response compared with the LG $(p<0.05)$, but not CG sites. Details of the measurements for the nine catchments are given in Supplementary material 8 and 9.

\subsection{1 | Influence of storm size and seasonality}

We identified 28 storms during our analysis period; including a 1 in 10-year storm event, two 1 in 4-year storm events and five 1 in 1.5-year events (Figure 4a). Two of these storms met requirements to be named by the UK Met Office, Storm Ciara (1 in 10-year event) and Storm Dennis (1 in 4-year event) (Parry et al., 2020). Both storms displayed characteristics of storms with longer return periods (Storm Ciara up to a 1 in 50-year event and Storm Dennis a 1 in 10-year event) (Figure 4b).
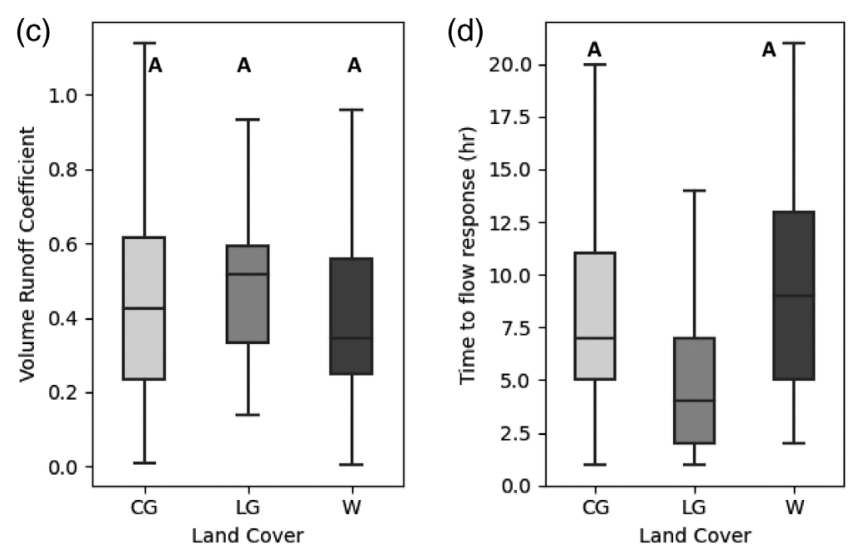

FIG URE 3 Distribution of (a) specific peak discharge $\left(\mathrm{mm} \cdot \mathrm{hr}^{-1}\right)$, (b) peak runoff coefficient, (c) volume runoff coefficient, (d) time to flow response (hr) for woodland (W), commons grazing (CG) and low-density grazing (LG) pasture shown as median (line), $25 \%$ and $75 \%$ (box), $5 \%$ and 95\% (whiskers). Sites which are not statistically different share a letter

We divided storms into those with a return period more than 1.5 years ( $n=8$ storms) and storms with a return period less than 1.5 years ( $n=20$ storms). For storms with a return period more than 1.5 years, woodlands exhibited significantly different $(p<0.05)$ SPD (Figure $5 \mathrm{a}$ ) and peak runoff coefficient (Figure $5 \mathrm{~b}$ ) compared with pasture: median SPD was 53\% lower than for CG sites and 58\% lower than LG sites, peak runoff coefficient was $48 \%$ lower than CG sites and $58 \%$ lower than LG sites. For storms with a return period more than 1.5 years, the median volume runoff coefficient for woodland sites was $26 \%$ lower than CG sites and $41 \%$ lower than LG sites $(p<0.05)$ (Figure 5c). Woodland catchments also exhibited lower SPD and peak runoff coefficients than pasture during Storm Ciara (Supplementary material 10 and Supplementary material 11).

Using the same storm classification as Kirby et al. (1991), we found woodland exhibited a significantly lower mean SPD $\left(2.35 \mathrm{~mm} \cdot \mathrm{hr}^{-1}\right)$ compared with pasture $\left(3.67 \mathrm{~mm} \cdot \mathrm{hr}^{-1}\right)$ for larger storms. However, there was no significant difference in mean SPD between woodland $\left(0.68 \mathrm{~mm} \cdot \mathrm{hr}^{-1}\right)$ and pasture $\left(0.51 \mathrm{~mm} \cdot \mathrm{hr}^{-1}\right)$ for smaller storms. We found woodlands had lower SPD and runoff coefficients compared with pasture in both summer and winter, with the largest differences in winter (Table 2). We found the cumulative flow above a certain threshold during a 14-day period in winter was lower at the woodland sites compared with pasture (Table 3). 

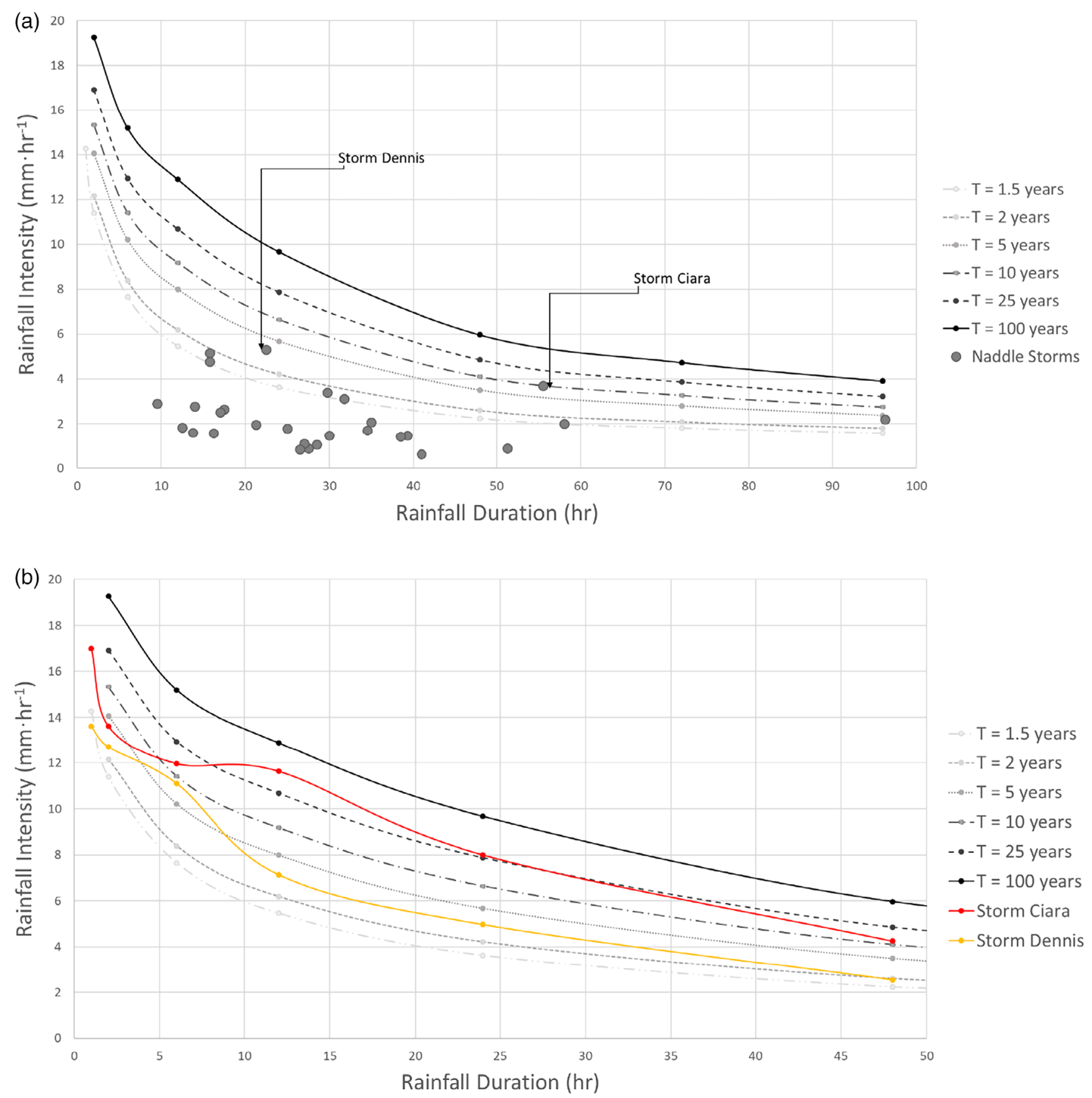

FIGURE 4 Intensity-duration-frequency (IDF) curve of wet Sleddale rainfall data from 1997 to 2021 for return periods, $T=1.5,2,5,10,25$, 100 years. (a) 28 storms identified at the Naddle rain gauge overlaid with grey circles. (b) Met office named storms, Ciara \& Dennis overlaid to show the range of storm intensities throughout each event

\subsection{2 | Hydrograph form and flashiness}

Figure 6 shows the medians of normalized hydrograph peaks for all storms exceeding the $97.5 \%$ frequency threshold. These medians are derived from individual storm data for each site, shown in full in Supplementary material 12 . Steeper rising and falling limbs indicate a flashier response, generally associated with more severe flooding from storm rainfall. It is evident that woodland sites are the least flashy, and pasture sites (particularly low-density pasture) the most flashy.

\section{4 | DISCUSSION}

Our study provides some of the first information of the impacts of mature semi-natural broadleaf woodlands in the UK on streamflow in 

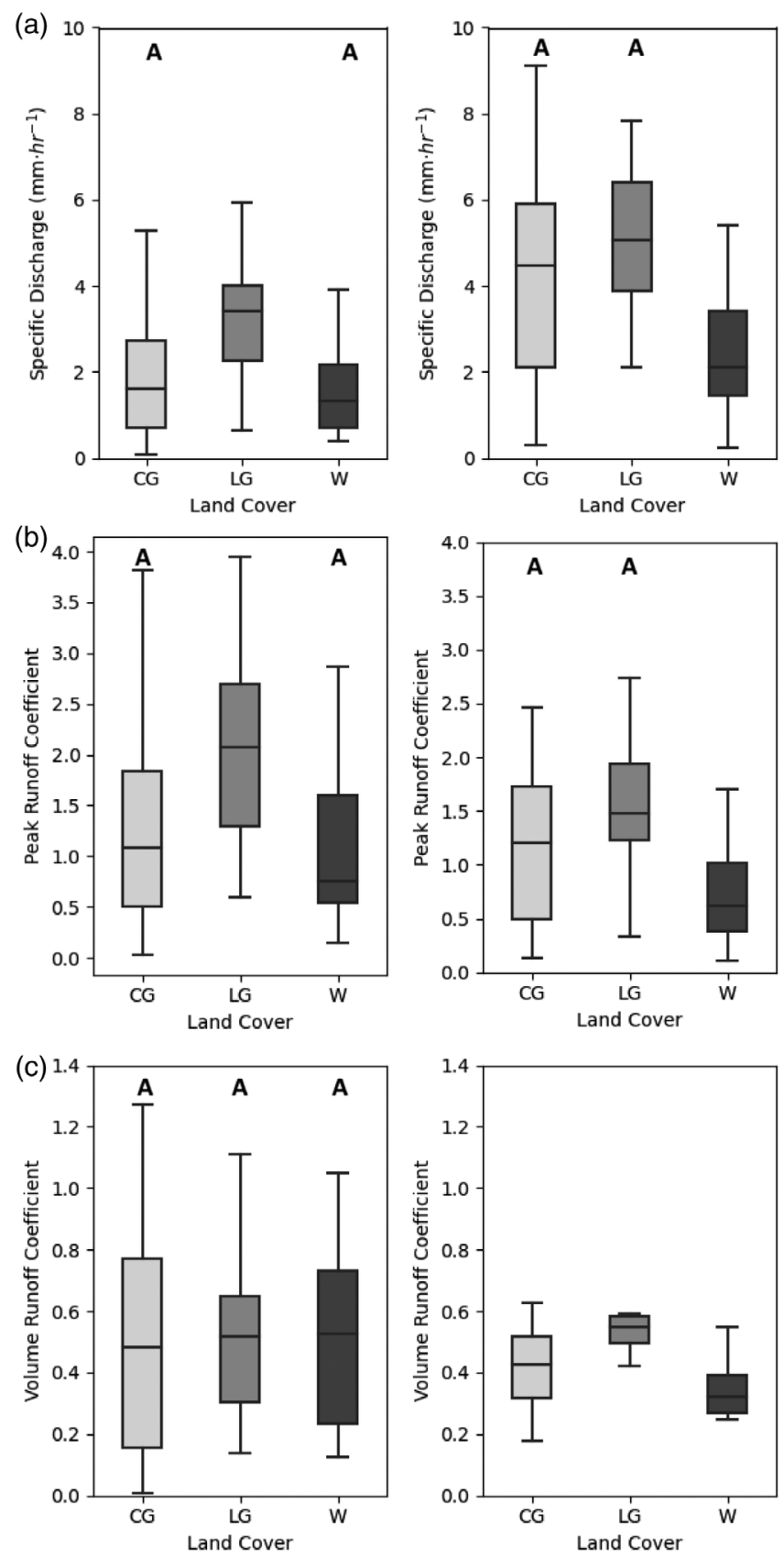

FIGURE 5 Comparison of streamflow for storms with return periods of less than (left hand panels) and more than (right hand panels) 1.5 years for woodland (W), commons grazing (CG) and lowdensity grazing (LG) pasture. (a) Specific peak discharge $\left(\mathrm{mm} \cdot \mathrm{hr}^{-1}\right.$ ), (b) peak runoff coefficient), (c) volume runoff coefficient shown as median (line), 25\% and 95\% (box), 5\% and 95\% (whiskers). Shown for sites which are not statistically different share a letter. Supplementary material 10 reports tabulated data

small $\left(<0.2 \mathrm{~km}^{2}\right)$ catchments. The lower specific peak flow, lower runoff coefficient and longer response time of mature semi-natural broadleaf woodlands compared with pasture will contribute to reduced peak flow downstream. In contrast to some previous studies, we found mature broadleaf woodland can reduce peak flow for larger storms (>1 mm.hr ${ }^{-1}$ ) and for storms with $>1.5$-year return periods.
Together this demonstrates the effectiveness of mature semi-natural broadleaf woodlands as a NFM method.

\section{1 | Comparison of streamflow response in semi- natural woodland and wood pasture}

Across all the storms analysed, we found that woodland sites typically had lower SPD, peak and volume runoff compared with grazed pasture sites by $23 \%-60 \%, 30 \%-60 \%$, and $21 \%-35 \%$ respectively. Peak runoff coefficients can be strongly influenced by characteristics of the storm event (Figure 5b), but in our analysis shows consistent behaviour with other streamflow metrics. Sriwongsitanon and Taesombat (2011) reported lower runoff coefficients for a forested area in comparison with an agricultural area. We found that the average time taken for flow to respond to storm events was $14 \%-50 \%$ longer in the woodland compared with pasture sites. Lana-Renault et al. (2011) found a forested catchment took $171 \%$ longer to respond than a formerly agricultural catchment, subsequently left to naturally regenerate. As in previous studies (e.g., Carroll et al., 2004; Chandler et al., 2018; Mawdsley et al., 2017; Wahl et al., 2003) we compared small catchments which are as similar as possible in all respects except land cover and assume differences in land cover drive difference in hydrological response (McCulloch \& Robinson, 1993). Flow response is dependent on antecedent conditions, which will be similar for our sites as they are closely located to each other. We note that it is not possible to identify catchments that are identical in all aspects, so it remains possible that catchment differences drive some of the observed differences in flow response (Lana-Renault et al., 2011; López-Ramírez et al., 2020). Establishing measurements in multiple small catchments (here three woodland and six pasture catchments) will help to reduce these uncertainties. Future work is needed to track changes in soil properties and streamflow as newly established broadleaf woodlands mature.

\subsection{Impact of storm size}

Previous studies have reported that forests reduce peak discharge during small flood events but not always during larger events (Dadson et al., 2017; Stratford et al., 2017). For example, Kirby et al. (1991) showed lower peak flows in a wooded catchment compared with a grassland catchment during smaller storms (discharge peaks $<1 \mathrm{~mm} \cdot \mathrm{hr}^{-1}$ ), but little difference during larger storms (discharge peaks $>1 \mathrm{~mm} \cdot \mathrm{hr}^{-1}$ ). Using the same storm classification, we found woodland exhibited a lower mean SPD $\left(2.35 \mathrm{~mm} \cdot \mathrm{hr}^{-1}\right)$ compared with pasture $\left(3.67 \mathrm{~mm} \cdot \mathrm{hr}^{-1}\right.$ ) for larger storms.

We also explored whether land use had different impacts for different storm return periods. Woodlands had a median volume runoff coefficient that was $26 \%-41 \%$ lower and peak runoff coefficient that was $48 \%-58 \%$ lower than pasture for storms with a return period greater than 1.5 years. Our study focused on mature, semi-natural woodlands consisting of native broadleaf tree species without any 
TA B LE 2 Summer and winter streamflow properties for woodland and pasture (commons grazing (CG) and low-density grazing (LG) combined due to data availability)

\begin{tabular}{|c|c|c|c|c|c|c|c|c|c|c|c|c|c|c|c|c|}
\hline & \multicolumn{4}{|c|}{ Specific peak discharge (SPD) $\left(\mathrm{mm} \cdot \mathrm{hr}^{-1}\right)$} & \multicolumn{4}{|c|}{ Peak runoff coefficient } & \multicolumn{4}{|c|}{ Volume runoff coefficient } & \multicolumn{4}{|c|}{ Time to flow response (hr) } \\
\hline & $n$ & $\boldsymbol{\mu}$ & $n$ & $\mu$ & $n$ & $\mu$ & $n$ & $\mu$ & $n$ & $\mu$ & $n$ & $\boldsymbol{\mu}$ & $n$ & $\mu$ & $n$ & $\mu$ \\
\hline Woodland & 12 & 0.0013 & 43 & 0.0019 & 12 & 0.80 & 42 & 0.89 & 10 & 0.50 & 37 & 0.42 & 12 & 9 & 45 & 10 \\
\hline Pasture & 36 & 0.0020 & 103 & 0.0035 & 36 & 1.15 & 99 & 1.64 & 40 & 0.37 & 83 & 0.61 & 36 & 6 & 106 & 8 \\
\hline
\end{tabular}

TABLE 3 Cumulative sum of flow above $1 \mathrm{~mm} \cdot \mathrm{hr}^{-1}$ and $2 \mathrm{~mm} \cdot \mathrm{hr}^{-1}$ flow thresholds

\begin{tabular}{lll} 
& \multicolumn{2}{l}{ Cumulative flow $(\mathrm{mm})$} \\
\cline { 2 - 3 } Land cover & $\mathbf{1 \mathrm { mm } \cdot \mathrm { hr } ^ { - 1 }}$ & $\mathbf{2 \mathrm { mm } \cdot \mathrm { hr } ^ { - 1 }}$ \\
\hline Commons Grazing & 283 & 102 \\
\hline Low-density Grazing & 270 & 189 \\
Woodland & 131 & 21 \\
\hline
\end{tabular}

drainage. In contrast, most previous UK studies have focused on conifer plantation with drains established prior to afforestation (Dadson et al., 2017; Kirby et al., 1991; Stratford et al., 2017) which may partly explain the difference in response to larger storms. Tembata et al. (2020) confirms that forest type is important, with broadleaf and mixed forests mitigating flooding whereas conifer forests did not.

Importantly, we found that the response to the largest storm event recorded in our study period, Storm Ciara, remained consistent with the response to other storm events. SPD, peak and volume runoff coefficients were lower in the wooded catchments compared to pasture. The hydrograph response shows the wooded catchments were less flashy during Storm Ciara with a slower rising and falling hydrograph with a smaller and later peak (Supplementary material 11). However, the impact of land cover on storm response during more extreme storm events, for example, 100 year return period, remain unquantified and are likely to show lesser effects than those demonstrated here. Longer data records are needed to capture such large storm events and allow for a more detailed analysis of the impacts of land cover as a function of storm size.

\section{3 | Seasonal differences in flood response}

We analysed the impacts of land cover during both winter and summer storms (Table 2).

Woodlands had lower SPD and runoff coefficients compared with pasture in both summer and winter, with the largest differences in winter. We found the cumulative flow above a certain threshold during a 14-day period in winter was lower at the woodland sites compared with pasture (Table 3). An increase in heavy wintertime rainfall across Northern England in recent decades highlights the need for flood management during winter months (Burt \& Ferranti, 2012; Orr \& Carling, 2006).

\subsection{Soil properties}

The difference in streamflow response between woodland and pasture sites, particularly in winter when differences in evapotranspiration will be more limited (Blyth et al., 2019; Robinson et al., 2020), can in part be explained by differences in their soil properties. Lower peak flows, lower runoff coefficients and longer times to flow response in woodland sites all indicate a more permeable catchment. This is confirmed by differences in topsoil permeability with our woodland sites having a median topsoil permeability 11-20 times greater than the pasture sites. Previous studies have also found woodland catchments to have more permeable soils, with topsoil $(<20 \mathrm{~cm})$ permeability 1.8-8 times greater than that of grazed permanent pasture (Table 4). The median topsoil permeability we measured for pasture sites $\left(1.47 \times 10^{-4}-2.78 \times 10^{-4} \mathrm{~m} \cdot \mathrm{s}^{-1}, 529-1000 \mathrm{~mm} \cdot \mathrm{hr}^{-1}\right)$ overlap previously reported values for pasture and field margins in Northern England: Wallace and Chappell (2019) reported median topsoil permeability of 21-2794 $\mathrm{mm} \cdot \mathrm{hr}^{-1}$ whereas Wallace et al., (2021) reported $317-8780 \mathrm{~mm} \cdot \mathrm{hr}^{-1}$. Hedgerows can also increase permeability, with topsoil permeability 20-30 times higher than pasture (Wallace \& Chappel, 2021; Holden et al., 2019). Individual trees within pasture have been shown to increase soil permeability up to $13 \mathrm{~m}$ from the tree (Chandler \& Chappell, 2008), though we did not observe this effect at our LG pasture sites.

A range of mechanisms have been proposed to explain the greater permeability of woodland and hedgerow soils compared with pasture. The root networks of trees and shrubs can generate macropores within the soil matrix that enhance permeability (Chandler \& Chappell, 2008; Wallace et al., 2021). The lower permeability of pasture soils can be due to topsoil compaction caused by livestock grazing (Carroll et al., 2004). Our pasture sites were only lightly grazed and we did not find pasture soils had higher bulk density that would be consistent with compaction. Wallace and Chappell (2019) found that aeration of pasture soils can increase saturated hydraulic conductivity and reduce overland flow. The lower permeability of pasture soils is known to increase runoff and contribute to downstream flooding (Alaoui et al., 2018). Conifer forests soils can have lower permeability compared with both broadleaf woodland and permanent pasture (Chappell et al., 1996; Gonzalez-Sosa et al., 2010), contributing to greater overland flow (Tembata et al., 2020). Many previous studies also found higher subsoil permeability in woodland soils, whereas we found no significant difference in soil permeability at $15 \mathrm{~cm}$ depth between woodland and pasture soils. This is likely due 


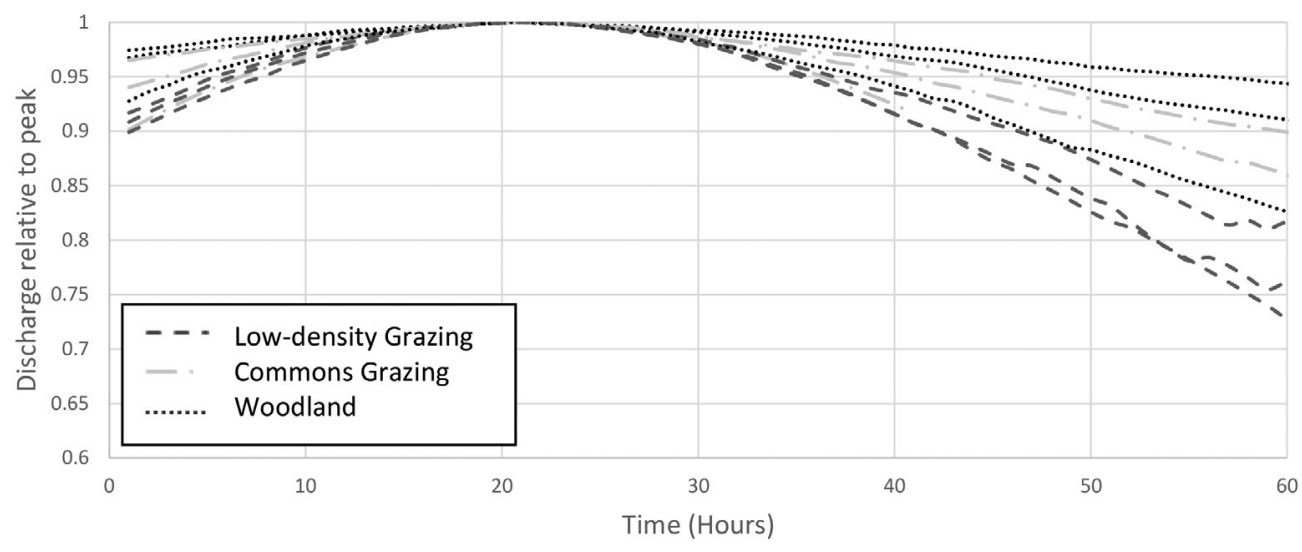

FIGURE 6 Median form of hydrograph peaks for all events exceeding the $97.5 \%$ threshold. Data normalized to $100 \%$ for the peak flow. Data from all storms shown in Supplementary material 12

TAB LE 4 Ratio between permeability (Kfs) of woodlands and grazed soils, comparing data from previous studies

\begin{tabular}{|c|c|c|c|}
\hline References & Vegetation & $\begin{array}{l}\text { Ratio of Kfs woodland } \\
\text { compared with grazed land }\end{array}$ & Depth $(\mathrm{cm})$ \\
\hline Agnese et al. (2011) & $40-50$ year-old broadleaf & 3.4 & $10-20$ \\
\hline Mawdsley et al. (2017) & 18 month-old saplings & 2.3 & $10-30$ \\
\hline \multirow[t]{2}{*}{ Zimmermann et al. (2006) } & Tropical forest & 4 & 12.5 \\
\hline & & 8 & 20 \\
\hline López-Ramirez et al. (2020) & Tropical montane & 4.8 & 20 \\
\hline This study & Mature broadleaf & $11-20$ & 5 \\
\hline
\end{tabular}

to the relatively thin soils in our upland sites, with the action of tree roots in the development of open pores more limited below $15 \mathrm{~cm}$.

We found LG pasture and woodland sites had significantly higher soil moisture when compared with CG pasture sites. The sparse tree planting in the LG sites may have contributed to the higher soil moisture in this area. Mawdsley et al. (2017) found tree planting can increase soil moisture within 18 months. Furthermore, higher levels of soil moisture are often attributed to lower levels of grazing ( $\mathrm{Xu}$ et al., 2014). Wallace and Chappell (2020) found that application of fertilizer and slurry to agriculturally improved pasture resulted in reduced summer soil moisture but increased autumn soil moisture potentially increasing downstream flood risk.

Some previous studies have found woodland soils to have $10 \%-$ $30 \%$ lower bulk density than other vegetation types (Agnese et al., 2011; Sharrow, 2007; Wahren, 2009). In contrast, Upson et al. (2016) found woodland soils had greater bulk density compared with pasture. We found woodlands exhibited the highest bulk density values, with a significant difference between woodland soils and LG soils. Our pasture sites were lightly grazed, possibly explaining the lack of compaction and lower bulk density.

In our study, livestock grazed the pasture sites whereas the woodland sites did not have any livestock grazing. The number of sheep in the UK has changed substantially in recent decades, increasing from 19.7 million in 1950 to 44.5 million in 1990 (Fuller \&
Gough, 1999), before declining around the turn of the century to 33.5 million in 2019 (DEFRA, 2020). Sheep numbers in the nearby Lune catchment (Cumbria) increased by a factor of five from 100000 in 1860 to 500000 in 1990 (Orr \& Carling, 2006). These large changes in livestock numbers are likely to have caused substantial impacts (O'connell et al., 2007). Stock grazing changes vegetation structure and composition (Milligan et al., 2016; Orr \& Carling, 2006) and can lead to soil compaction, a reduction in soil permeability (Alaoui et al., 2018) and soil water storage (Meyles et al., 2006). Loss of vegetation and soil compaction can increase flood risk, with simulated flood peaks in a UK upland catchment increased by $33 \%$ under light grazing and $82 \%$ under heavy grazing (Gao et al., 2017). The lower grazing levels found in our LG sites would be anticipated to lead to higher soil permeability and lower peak flow compared with CG sites. In contrast, we found lower rates of permeability and higher SPD and runoff coefficients at the LG compared with CG sites. Overall grazing pressures across both the CG and LG pasture sites in our study were relatively similar at around 0.1 livestock unit per hectare (Table 1), with the main difference being less wintertime grazing in the LG sites. Our study does not provide any information on the impacts of higher grazing pressure that is found across much of the UK uplands, exceeding four sheep per hectare in some locations (Orr \& Carling, 2006). Variability in grazing pressure within a site can result in areas favoured for grazing experiencing more compaction (Orr \& Carling, 2006) 
reducing the downward mixing of organic material, decreasing permeability. The recovery of vegetation after a reduction in grazing should reduce rates of overland flow (Bond et al., 2020), with impacts on downstream flooding. In our study reduced grazing was introduced fairly recently ( $\sim 7$ years ago) and whilst relatively little is known about the effects of reducing stock grazing pressures, it may take 4862 years to see the benefits of reduced grazing due to the long-term soil degradation caused by intensive sheep-grazing and slow rates of recovery (Marrs et al., 2018; Marrs et al., 2020).

\subsection{Implications for policy}

Our analysis demonstrates the importance of semi-natural broadleaf woodlands in modifying soil properties and reducing flood peaks in small $\left(<0.2 \mathrm{~km}^{2}\right)$ catchments, even for larger storm events. A key challenge remains to assess the impacts of woodland at larger scales (Dadson et al., 2017). Data collected here can be used to inform parameter choice in flood prediction models, which can then be used to upscale results to understand the impacts of semi-natural woodlands on downstream flooding in larger catchments (Gao et al., 2017; Jackson et al., 2008; Mclntyre et al., 2013). Our analysis includes a number of large storms, including two storms that met the UK Met Office criteria for a named storm (Storm Dennis and Storm Ciara). Storm Ciara resulted in widespread disruption and flooding within Northern England, so our results are relevant for flood risk management. However, the smaller number of recorded peak flows with increasing peak size makes it difficult to demonstrate a statistically significant change in flow response for the largest events (BurgessGamble et al., 2017).

We show that semi-natural broadleaf woodland has more permeable soils resulting in lower peak flood discharge compared with pasture grazed by sheep, the dominant land use in much of the UK uplands. All the pasture sites in our study had relatively low grazing intensity ( 0.1 sheep/hectare)-the difference in soil permeability and streamflow between woodland and pasture may be even greater for pasture with the higher grazing intensity more typical of the UK uplands (DEFRA, 2020). Our study suggests that restoring or converting upland pasture to semi-natural woodland would help reduce downstream flood risk. Previous studies have found that soil permeability can increase rapidly after tree planting (Mawdsley et al., 2017) so the benefits to reduced flooding could be realized quickly. In contrast, reductions in grazing without tree planting may result in relatively slow changes in soil properties suggesting tree planting may be necessary in many locations if rapid changes are needed.

In the UK, agricultural subsidies have supported upland sheep farming in recent decades (Hardaker, 2018). Planned changes in agricultural subsidy and the need to mitigate climate change and reach net-zero carbon emissions (Paris Agreement, 2015) may increase future interest in woodland creation in the UK uplands. The UK government has committed to creating 30000 hectares of new woodland per year (DEFRA, 2018; Jordan \& Wentworth, 2021), which would increase UK woodland cover to about $18 \%$ in 2050. A large proportion of these new woodlands will likely be established in the uplands (Murphy et al., 2020). Broadleaf woodland accounted for $43 \%$ of the new woodland created in the UK in 2019-2020 (Forestry Commission, 2020) and is likely to make up a substantial component of future woodland creation under the UK's 25 Year Environment Plan (DEFRA, 2018). Our work suggests creation of new broadleaf woodlands will help to reduce flood risk. As changes to upland landuse and management occur, it is essential that the influence of those changes to flood risk is monitored and understood (Pender, 2006). An integrated policy perspective combining climate and flood mitigation alongside the additional benefits of woodlands is required to maximize the societal benefits of new woodlands. Future work is needed to identify the most beneficial locations for woodland creation in terms of flood mitigation and to understand how climate and flood mitigation vary for different woodland types.

\section{5 | CONCLUSION}

Most previous work on the hydrological impacts of forests, especially the impacts on flooding, has been based on conifer forests, typically plantations. The aim of this study was to explore the potential flood mitigation impacts of semi-natural broadleaf woodlands. We established an experimental correlation catchment study in northwest England, to identify differences in streamflow and soil properties between semi-natural broadleaf woodland and permanent pasture. Catchments were selected with similar size, elevation, soil type and geology but different land use.

We found that semi-natural broadleaf woodlands can reduce specific peak discharge by $23 \%-60 \%$, peak runoff coefficients by $30 \%-$ $60 \%$ and volume runoff coefficient by $21 \%-35 \%$, compared with pasture. Woodland sites take $14 \%-50 \%$ longer to respond to storm events than pasture sites. Crucially, we found woodlands reduced runoff for both small and large storms. For storms with a return period of more than 1.5 years, woodlands reduced peak runoff coefficient by $48 \%-58 \%$ and volume runoff coefficient by $26 \%-41 \%$. Differences in flood response can be explained by the more permeable woodland soils, 11-20 times greater than pasture soil irrespective of the higher bulk density measured.

Our study demonstrates that semi-natural broadleaf woodlands in the uplands can reduce rainfall-generated flooding, strengthening the case for broadleaf woodland creation as a land use management method of NFM. Our study is based on small catchments $\left(<0.2 \mathrm{~km}^{2}\right)$ and relatively short ( $\leq 10$ year) storm return periods. Data from our study needs to be used within models to predict the impacts of broadleaf woodlands on downstream flooding in larger catchments and for bigger storm events. Empirical studies are now needed to monitor the long-term impact of reduced grazing levels, tree planting and woodland creation on streamflow and soil properties.

\section{ACKNOWLEDGEMENTS}

This research has been supported by the United Bank of Carbon (UBoC) and the European Research Council (ERC) under the 
European Union's Horizon 2020 Research and Innovation programme (DECAF project; grant no. 771492). DVS acknowledges a Philip Leverhulme Prize. We thank United Utilities, and RSPB Haweswater, and Spike Webb, for granting access, permissions, and equipment storage. We also thank volunteers for assisting with field measurements.

\section{DATA AVAILABILITY STATEMENT}

The data that support the findings of this study are openly available in the University of Leeds repository at https://doi.org/10.5518/950.

\section{ORCID}

Felicity Monger (D) https://orcid.org/0000-0002-1780-2144

Dominick V Spracklen (D) https://orcid.org/0000-0002-7551-4597

Mike J Kirkby (D) https://orcid.org/0000-0003-2036-1770

\section{REFERENCES}

Agnese, C., Bagarello, V., Baiamonte, G., \& lovino, M. (2011). Comparing Physical Quality of Forest and Pasture Soils in a Sicilian Watershed. Soil Science Society of America Journal, 75(5), 1958-1970. https://doi. org/10.2136/sssaj2011.0044

Ahmad-Shah, A., \& Rieley, J. (1989). Influence of tree canopies on the quantity of water and amount of chemical elements reaching the peat surface of a basin mire in the midlands of England. The Journal of Ecology, 77, 357-370. https://doi.org/10.2307/2260755

Alaoui, A., Rogger, M., Peth, S., \& Blöschl, G. (2018). Does soil compaction increase floods? A review. Journal of Hydrology, 557, 631-642.

Archer, D. R. (2007). The use of flow variability analysis to assess the impact of land use change on the paired Plynlimon catchments, midWales. Journal of Hydrology, 347, 487-496.

Archer, N. A. L., Bonell, M., Coles, N., Macdonald, A. M., Auton, C. A., \& Stevenson, R. (2013). Soil characteristics and landcover relationships on soil hydraulic conductivity at a hillslope scale: A view towards local flood management. Journal of Hydrology, 497, 208-222.

Ashbrook, J. D. 2020. Assessing the effectiveness of leaky dams at Crimsworth dean, Hebden bridge.

Barrett, P., Hunter, J., Miller, J. T., Hsu, J-C., \& Greenfield, P. (2005). Matplotlib--A portable python plotting package. Astronomical data analysis software and systems, XIV, 91.

Bathurst, J., Birkinshaw, S., Johnson, H., Kenny, A., Napier, A., Raven S., \& Robinson, J. (2018). Runoff, flood peaks and proportional response in a combined nested and paired forest plantation/peat grassland catchment. Journal of Hydrology, 564, 916-927.

Bathurst, J. C., Fahey, B., Iroumé, A. \& Jones, J. (2020). Forests and floods: Using field evidence to reconcile analysis methods, 34, 3295-3310.

Beschta, R. L., Pyles, M. R., Skaugset, A. E., \& Surfleet, C. G. (2000). Peakflow responses to forest practices in the western cascades of Oregon, USA. Journal of Hydrology, 233, 102-120.

Birkinshaw, S. J., Bathurst, J. C., \& Robinson, M. (2014). 45 years of nonstationary hydrology over a forest plantation growth cycle, Coalburn catchment, northern England. Journal of Hydrology, 519, 559-573.

Blyth, E. M., Martínez-De La Torre, A., \& Robinson, E. L. (2019). Trends in evapotranspiration and its drivers in Great Britain: 1961 to 2015, 43, 666-693.

Bond, S., Kirkby, M. J., Johnston, J., Crowle, A., \& Holden, J. (2020). Seasonal vegetation and management influence overland flow velocity and roughness in upland grasslands. Hydrological Processes, 34, 37773791.

Bronstert, A., Niehoff, D., \& Bürger, G. (2002). Effects of climate and landuse change on storm runoff generation: Present knowledge and modelling capabilities. Hydrological Processes, 16, 509-529.
Brown, A. E., Zhang, L., Mcmahon, T. A., Western, A. W., \& Vertessy, R. A. (2005). A review of paired catchment studies for determining changes in water yield resulting from alterations in vegetation. Journal of Hydrology, 310, 28-61.

Burgess-Gamble, L., Ngai, R., Wilkinson, M., Nisbet, T., Pontee, N., Harvey, R. \& Maslen, S. (2017). Working with natural processesevidence directory. Environmental Agency, Report No. SC150005.

Burt, T. P., \& Ferranti, E. J. S. (2012). Changing patterns of heavy rainfall in upland areas: A case study from northern England. International Journal of Climatology, 32, 518-532.

Calder, I. R., \& Aylward, B. (2006). Forest and floods: Moving to an evidence-based approach to watershed and integrated flood management. Water International, 31, 87-99.

Carroll, Z. L., Bird, S. B., Emmett, B. A., Reynolds, B. \& Sinclair, F. (2004). Can tree shelterbelts on agricultural land reduce flood risk?. Soil Use and Management 20(3), 357-359. https://doi.org/10.1111/j.14752743.2004.tb00381.x

Chandler, K. R., \& Chappell, N. A. (2008). Influence of individual oak (Quercus robur) trees on saturated hydraulic conductivity. Forest Ecology and Management, 256, 1222-1229.

Chandler, K. R., Stevens, C. J., Binley, A., \& Keith, A. M. (2018). Influence of tree species and forest land use on soil hydraulic conductivity and implications for surface runoff generation. Geoderma, 310, 120-127.

Chappell, N., Stobbs, A., Ternan, L., \& Williams, A. (1996). Localised impact of Sitka spruce (Picea sitchensis [bong.] Carr.) on soil permeability. Plant and Soil, 182, 157-169.

Cranfield University. 2019. The Soils Guide [Online]. Available: www. landis.org.uk. [Accessed].

Dadson, S. J., Hall, J. W., Murgatroyd, A., Acreman, M., Bates, P., Beven, K., Heathwaite, L., Holden, J., Holman, I. P., Lane, S. N., O'Connell, E., Penning-Rowsell, E., Reynard, N., Sear, D., Thorne, C. \& Wilby, R. 2017. A restatement of the natural science evidence concerning catchment-based 'natural' flood management in the UK. Proceedings of the Royal Society A: Mathematical, Physical and Engineering Science, 473.

DEFRA (2018). A green future: Our 25 year plan to improve the environment. In Great Britain. Department For Environment, F. R. A.

DEFRA. 2020. Livestock numbers in England and the UK.

Delta-T, D. (1999). Theta probe soil moisture sensor user manual: Type ML2x. Delta-T Devices Ltd.

Digimap. 2021. Digimap ordnance survey collection. https://digimap. edina.ac.uk/

Dixon, S. J., Sear, D. A., Odoni, N. A., Sykes, T., \& Lane, S. N. (2016). The effects of river restoration on catchment scale flood risk and flood hydrology. Earth Surface Processes Landforms., 41, 997-1008.

Elrick, D. E., \& Reynolds, W. D. (1986). An analysis of the percolation test based on three-dimensional saturated-unsaturated flow from a cylindrical test hole. Soil Science, 142, 308-321.

Farley, K. A., Jobbágy, E. G., \& Jackson, R. B. (2005). Effects of afforestation on water yield: A global synthesis with implications for policy. Global Change Biology, 11, 1565-1576.

Forestry Commission 2020. Woodland areas and planting.

Fuller, R., \& Gough, S. (1999). Changes in sheep numbers in Britain: Implications for bird populations. Biological Conservation, 91, 73-89.

Gallart, F., \& Clotet, N. (1987). Hydraulic geometry as a method for analysis of uninstrumented catchments. In V. Gardiner (Ed.), In international geomorphology 1986. Wiley.

Gallart, F., \& Llorens, P. (2003). Catchment management under environmental change: Impact of land cover change on water resources. Water International, 28, 334-340.

Gao, J., Holden, J., \& Kirkby, M. (2017). Modelling impacts of agricultural practice on flood peaks in upland catchments: An application of the distributed Topmodel. Hydrological Processes, 31, 4206-4216.

Gifford, G. F., \& Hawkins, R. H. (1978). Hydrologic impact of grazing on infiltration: A critical review, 14, 305-313. 
Gonzalez-Sosa, E., Braud, I., Dehotin, J., Lassabatère, L., AnguloJaramillo, R., Lagouy, M. \& Michel, K. ... (2010). Impact of land use on the hydraulic properties of the topsoil in a small French catchment, 24, 2382-2399.

Greenwood, K., Macleod, D., \& Hutchinson, K. (1997). Long-term stocking rate effects on soil physical properties. Australian Journal of Experimental Agriculture., 37, 413-419.

Hall, J., Arheimer, B., Borga, M., Brázdil, R., Claps, P., Kiss, A., ... Blöschl, G. (2014). Understanding flood regime changes in Europe: A state-ofthe-art assessment. Hydrology and Earth System Sciences, 18, 27352772.

Hankin, B., Metcalfe, P., Johnson, D., Chappell, N. A., Page, T., Craigen, I., ... Beven, K. (2017). Strategies for testing the impact of natural flood risk management measures. In T. Hromadka \& P. Rao (Eds.), Flood Risk Management. Rijeka.

Hardaker, A. (2018). Is forestry really more profitable than upland farming? A historic and present day farm level economic comparison of upland sheep farming and forestry in the UK. Land Use Policy, 71, 98-120.

Holden, J., Chapman, P., Evans, M., Hubacek, K., Kay, P. \& Warburton, J. 2007. Vulnerability of organic soils in England and Wales final technical report to DEFRA and countryside Council for Wales DEFRA project SP0532.

Holden, J., Grayson, R. P., Berdeni, D., Bird, S., Chapman, P. J., Edmondson, J. L., ... Leake, J. R. (2019). The role of hedgerows in soil functioning within agricultural landscapes. Agriculture, Ecosystems \& Environment., 273, 1-12.

Hudson, J., Gilman, K. \& Calder, I. 1997. Land use and water issues in the uplands with reference to the Plynlimon study.

lacob, O., Brown, I., \& Rowan, J. (2017). Natural flood management, land use and climate change trade-offs: The case of Tarland catchment, Scotland. Hydrological Sciences Journal, 62, 1931-1948.

International Organisation For Standardisation. (1980). Water flow measurement in open channels using weirs and Venturi flumes. Part 1 : Thin-plate weirs, international organisation for standardisation. ISO 1438-1.

Jackson, B.M., Wheater, H.S., Mcintyre, N.R., Chell, J., Francis, O.J., Frogbrook, Z., Marshall M., Reynolds, B., \& Solloway, I. (2008). The impact of upland land management on flooding: Insights from a multiscale experimental and modelling programme. Journal of Flood Risk Management., 1, 71-80.

Johnson, R. C. 1995. Effects of upland afforestation on water resourcesthe Balquhidder experiment 1981-1991, Institute of Hydrology.

Jordan, M. \& Wentworth, J. (2021). Woodland creation. The parliamentary Office of Science and technology. London.

Kenworthy, J. M. (2014). Regional weather and climates of the British Isles-part 7: North West England and the Isle of Man, 69, 87-93.

Kirby, C., Newson, M., \& Gilman, K. (1991). Plynlimon research: The first two decades. Institute of Hydrology.

Kulin, G. \& Compton, P. R. 1975. A guide to methods and standards for the measurement of water flow, US: Department of Commerce, National Bureau of Standards.

Kundzewicz, Z. W., Kanae, S., Seneviratne, S. I., Handmer, J., Nicholls, N., Peduzzi, P., ... Mach, K. (2014). Flood risk and climate change: Global and regional perspectives. Hydrological Sciences Journal, 59, 1-28.

Lana-Renault, N., Latron, J., Karssenberg, D., Serrano-Muela, P., Regüés, D., \& Bierkens, M. F. P. (2011). Differences in stream flow in relation to changes in land cover: A comparative study in two subMediterranean mountain catchments. Journal of Hydrology, 411, 366-378.

Law, F. (1956). The effect of afforestation upon the yield of water catchment areas. Journal of the British Waterworks Association, 38 , 489-494.

López-Ramírez, S. M., Sáenz, L., Mayer, A., Muñoz-Villers, L. E., Asbjornsen, H., Berry, Z. C., ... Gómez-Aguilar, L. R. (2020). Land use change effects on catchment streamflow response in a humid tropical montane cloud forest region, Central Veracruz, Mexico. Hydrological Processes, 34(16), 3555-3570.

Marrs, R. H., Lee, H., Blackbird, S., Connor, L., Girdwood, S. E., O'Connor, M., ... Chiverrell, R. C. (2020). Release from sheep-grazing appears to put some heart back into upland vegetation: A comparison of nutritional properties of plant species in long-term grazing experiments. Annals of Applied Biology, 177, 152-162.

Marrs, R. H., Sánchez, R., Connor, L., Blackbird, S., Rasal, J., \& Rose, R. (2018). Effects of removing sheep grazing on soil chemistry, plant nutrition and forage digestibility: Lessons for rewilding the British uplands. Annals of Applied Biology, 173, 294-301.

Marshall, M., Ballard, C., Frogbrook, Z., Solloway, I., Mcintyre, N., Reynolds, B., \& Wheater, H. (2014). The impact of rural land management changes on soil hydraulic properties and runoff processes: Results from experimental plots in upland UK. Hydrological Processes, 28, 2617-2629.

Marshall, M. R., Francis, O. J., Frogbrook, Z. L., Jackson, B. M., Mcintyre, N., Reynolds, B., ... Chell, J. (2009). The impact of upland land management on flooding: Results from an improved pasture hillslope. Hydrological Processes: An International Journal, 23, 464-475.

Mawdsley, T., Chappell, N., \& Swallow, E. (2017). Hydrological change on Tebay common following fencing and tree planting: A preliminary dataset. Lancaster University.

McCulloch, J. S., \& Robinson, M. (1993). History of forest hydrology. Journal of Hydrology, 150, 189-216.

McIntyre, N., Ballard, C., Bruen, M., Bulygina, N., Buytaert, W., Cluckie, I., ... Wheater, H. (2013). Modelling the hydrological impacts of rural land use change. Hydrology Research, 45, 737-754.

Merz, R., Blöschl, G., \& Parajka, J. (2006). Spatio-temporal variability of event runoff coefficients. Journal of Hydrology, 331(3), 591-604.

Met Office. 2020. UK climate averages. www.metoffice.gov.uk/public/ weather/climate/.

Meyles, E., Williams, A., Ternan, L., \& Dowd, J. (2003). Runoff generation in relation to soil moisture patterns in a small Dartmoor catchment, Southwest England. Hydrological Processes, 17(2), 251-264.

Meyles, E. W., Williams, A. G., Ternan, J. L., Anderson, J. M., \& Dowd, J. F. (2006). The influence of grazing on vegetation, soil properties and stream discharge in a small Dartmoor catchment, Southwest England, UK. Earth Surface Processes and Landforms, 31, 622-631.

Milligan, G., Rose, R. J., \& Marrs, R. H. (2016). Winners and losers in a long-term study of vegetation change at moor House NNR: Effects of sheep-grazing and its removal on British upland vegetation. Ecological Indicators, 68, 89-101.

Murphy, T. R., Hanley, M. E., Ellis, J. S., \& Lunt, P. H. (2020). Native woodland establishment improves soil hydrological functioning in UKupland pastoral catchments. Land Degradation \& Development, 32, 10341045.

Nguyen, M., Sheath, G., Smith, C., \& Cooper, A. (1998). Impact of cattle treading on hill land: 2. Soil physical properties and contaminant runoff. New Zealand Journal of Agricultural Research, 41, 279-290.

Nicholson, A. R., O'Donnell, G. M., Wilkinson, M. E., \& Quinn, P. F. (2020). The potential of runoff attenuation features as a natural flood management approach. Journal of Flood Risk Managemen., 13, e12565.

Nisbet, T. (2005). Water use by trees. Forestry Commission.

Nisbet, T. \& Broadmeadow, S. Opportunity Mapping for Trees and Floods, Final Report to Parrett Catchment Project Wet Woodland Group. Forest Research. Surrey, UK.

Nisbet, T. \& Thomas, H. 2006. The role of woodland in flood control: A landscape perspective.

O'connell, P. E., Ewen, J., O'Donnell, G., \& Quinn, P. (2007). Is there a link between agricultural land-use management and flooding? Hydrology and Earth System Sciences, 11, 96-107.

Orr, H. G., \& Carling, P. A. (2006). Hydro-climatic and land use changes in the river lune catchment, north West England, implications for catchment management. River Research and Applications, 22, 239-255. 
Palmer, R., \& Smith, R. J. (2013). Soil structural degradation in SW England and its impact on surface-water runoff generation. Soil Use Management., 29, 567-575.

Paris Agreement \& UNFCCC (2015). Paris Agreement. In (Ed.), FCCC/CP/2015/L.9/Rev1.

Parry, S., Barker, L., Sefton, C., Hannaford, J., Turner, S., Muchan, K. \& Pennington, C. ... 2020. Briefing note. Severity of the February 2020 floods-preliminary analysis.

Pender, G. (2006). Briefing: Introducing the flood risk management research consortium. In Proceedings of the Institution of Civil Engineerswater management (pp. 3-8). Thomas Telford Ltd.

Priestley, S. (2017). Flood risk management and funding. House of Commons Library.

Quinn, P., O'Donnell, G., Nicholson, A., Wilkinson, M., Owen, G., Jonczyk, J., Barber N., Hardwick, M., \& Davies, G. (2013). Potential use of runoff attenuation features in small rural catchments for flood mitigation. Newcastle, Newcastle University.

Reynolds, W. (2008). Saturated hydraulic properties: Well permeameter. In M.R Carter \& E.G. Gregorich (Eds.), Soil sampling and methods of analysis, 2, 1025-1042. Boca Raton, FL: CRC Press.

Roberts, J., \& Rosier, P. (2005). The impact of broadleaved woodland on water resources in lowland UK: III. The results from black wood and Bridgets farm compared with those from other woodland and grassland sites. Hydrology and Earth System Sciences, 9, 614-620.

Robinson, E. L., Blyth, E. M., Clark, D. B., Comyn-Platt, E., \& Rudd, A. C. (2020). Climate hydrology and ecology research support system potential evapotranspiration dataset for Great Britain (1961-2017) [CHESS-PE]. NERC Environmental Information Data Centre.

Robinson, M. 1998. 30 years of forest hydrology changes at Coalburn: Water balance and extreme flows.

Robinson, M., Cognard-Plancq, A. L., Cosandey, C., David, J., Durand, P., Führer, H. W., ... Zollner, A. (2003). Studies of the impact of forests on peak flows and baseflows: A European perspective. Forest Ecology and Management, 186, 85-97.

Robinson, M., \& Dupeyrat, A. (2005). Effects of commercial timber harvesting on streamflow regimes in the Plynlimon catchments, midWales, 19, 1213-1226.

Rogger, M., Agnoletti, M., Alaoui, A., Bathurst, J. C., Bodner, G., Borga, M., ... Blöschl, G. (2017). Land use change impacts on floods at the catchment scale: Challenges and opportunities for future research. Water Resources Research, 53, 5209-5219.

RSBP. (2015). Farming with nature at RSPB Haweswater. RSPB Haweswater.

Sansom, A. (1999). Upland vegetation management: The impacts of overstocking. Water Science and Technology, 39, 85-92.

Seddon, N., Chausson, A., Berry, P., Girardin, C. A. J., Smith, A., \& Turner, B. (2020). Understanding the value and limits of nature-based solutions to climate change and other global challenges, 375, 20190120.

Sharrow, S. H. (2007). Soil compaction by grazing livestock in silvopastures as evidenced by changes in soil physical properties. Agroforestry Systems, 71, 215-223.

Spray, C., Arthur, S., Bergmann, E., Bell, J., Beevers, L. \& Blanc, J. 2016. Land management for increased flood resilience.

Sriwongsitanon, N., \& Taesombat, W. (2011). Effects of land cover on runoff coefficient. Journal of Hydrology, 410, 226-238.

Stevens, A. J., Clarke, D., \& Nicholls, R. J. (2016). Trends in reported flooding in the UK: 1884-2013. Hydrological Sciences Journal, 61, 50-63.

Stratford, C. M. J., House, A., Old, G., Acreman, M., Duenas-Lopez, M. A., Nisbet, T., ... Tickner, D. (2017). Do trees in UK-relevant river catchments influence fluvial flood peaks?: A systematic review. NERC/Centre for Ecology \& Hydrology.

Tembata, K., Yamamoto, Y., Yamamoto, M., \& Matsumoto, K. I. (2020). Don't rely too much on trees: Evidence from flood mitigation in China. Science of The Total Environment., 732, 138410.
Terpilowski, M. A. (2019). Scikit-posthocs: Pairwise multiple comparison tests in python, $4,1169$.

Thomas, H., \& Nisbet, T. (2012). Modelling the hydraulic impact of reintroducing large woody debris into watercourses. Journal of Flood Risk Management., 5, 164-174.

Upson, M. A., Burgess, P. J., \& Morison, J. I. L. (2016). Soil carbon changes after establishing woodland and agroforestry trees in a grazed pasture. Geoderma, 283, 10-20.

Virtanen, P., Gommers, R., Burovski, E., Oliphant, T. E., Cournapeau, D., Weckesser, W., ... Wilson, J. J. Z. (2019). scipy/scipy. SciPy, 1(2), 1.

Wahl, N. A., Bens, O., Schäfer, B., \& Hüttl, R. F. (2003). Impact of changes in land-use management on soil hydraulic properties: Hydraulic conductivity, water repellency and water retention. Physics and Chemistry of the Earth, Parts A/B/C, 28, 1377-1387.

Wahren, A., Feger, F.H., Schwarzel K., \& Munch, A. (2009). Land-use effects on flood generation - Considering soil hydraulic measurements in modelling. Advances in Geosciences, 21, 99-107.

Wallace, E. E., \& Chappell, N. A. (2019). Blade aeration effects on nearsurface permeability and overland flow likelihood on two Stagnosol pastures in Cumbria. UK., 48, 1766-1774.

Wallace, E. E., \& Chappell, N. A. (2020). A statistical comparison of spatiotemporal surface moisture patterns beneath a semi-natural grassland and permanent pasture: From drought to saturation. Hydrological Processes, 34, 3000-3020.

Wallace, E., Mcshane, G., Tych, W., Kretzschmar, A., Mccann, T., \& Chappell, N. A. (2021). The effect of hedgerow wild-margins on topsoil hydraulic properties, and overland-flow incidence, magnitude and water-quality. Hydrological Processes, 35(3), e14098.

Wheater, H., \& Evans, E. (2009). Land use, water management and future flood risk. Land Use Policy, 26, S251-S264.

Wingfield, T., Macdonald, N., Peters, K., Spees, J., \& Potter, K. (2019). Natural flood management: Beyond the evidence debate. Area, 51, 743-751.

Wolman, M. G., \& Miller, J. P. (1960). Magnitude and frequency of forces in geomorphic processes. The Journal of Geology, 68(1), 54-74.

Xu, M.-Y., Xie, F., \& Wang, K. (2014). Response of vegetation and soil carbon and nitrogen storage to grazing intensity in semi-arid grasslands in the agro-pastoral zone of northern China. PLoS One, 9, e96604.

Young, C. B., Mcenroe, B. M., \& Rome, A. C. (2009). Empirical determination of rational method runoff coefficients. Journal of Hydrologic Engineering, 14, 1283-1289.

Zhang, M., Liu, N., Harper, R., Li, Q., Liu, K., Wei, X., ... Liu, S. (2017). A global review on hydrological responses to forest change across multiple spatial scales: Importance of scale, climate, forest type and hydrological regime. Journal of Hydrology, 546, 44-59.

Zimmermann, B., Elsenbeer, H., \& De Moraes, J. M. (2006). The influence of land-use changes on soil hydraulic properties: Implications for runoff generation. Forest Ecology and Management, 222, 29-38.

\section{SUPPORTING INFORMATION}

Additional supporting information may be found in the online version of the article at the publisher's website.

How to cite this article: Monger, F., V Spracklen, D., J Kirkby, M., \& Schofield, L. (2022). The impact of semi-natural broadleaf woodland and pasture on soil properties and flood discharge. Hydrological Processes, 36(1), e14453. https://doi. org/10.1002/hyp.14453 